\title{
Oscillators: Phenomenological Mappings and Analogies Second Part: Structural Analogy and Chains
}

\author{
Katica Stevanović-Hedrih ${ }^{1)}$ \\ Ana Ivanović-Šašić ${ }^{2)}$ \\ Julijana Simonović ${ }^{3)}$ \\ Ljiljana Kolar-Anićs) \\ Željko Čupić ${ }^{2)}$
}

\begin{abstract}
New analytical and numerical results of dynamics for both linear and nonlinear system with two degrees of freedom are presented. For the mechanical chain system with two degrees of freedom, oscillations are investigated analytically and numerically with corresponding comparison between free and forced oscillatory dynamics of linear and nonlinear system. Using the Mihailo Petrovic่'s theory of elements of mathematical phenomenology, the phenomenological mappings in vibrations, signals, resonances and dynamical absorptions in models with two degrees of freedom - abstractions of different real system dynamics are identified, as well as in eigen time functions of multi-deformable coupled body system dynamics, and presented. Mathematical description of a chain mechanical system with two mass particles coupled by linear and nonlinear elastic springs and with two degree of freedom is given. By the analysis of corresponding solutions for free and forced vibrations, series of related two-frequency regimes and resonant states, as well as dynamical absorption states, are identified. Phenomenological mappings are used to explain dynamics in two deformable body (beams, plates or membranes) systems. In short, new analytical and numerical results of linear and non-linear dynamics of a system with two-degrees of freedom in analogy with eigen time functions oscillations of transversal vibrations of two body system dynamics are presented. Structural analogies are identified between eigen time functions of different multi-coupled deformable body transversal vibrations (plates, beams, belts or membranes). Mathematical phenomenology elements and phenomenological mappings are applied in the scientific results integration. Mathematical analogy and phenomenological mappings of linear and nonlinear singular phenomena in discrete and multi-body system vibrations (torsional system, multi-pendulum system, coupled electrical circuit and multi-deformable-body oscillations-beams, plates, membranes) are performed. Structural analogy is used to explain phenomenological mappings between displacements of the mass particles in discrete system and eigen time functions in one eigen amplitude mode of dynamics in two coupled deformable body (beams, plates or membranes) systems.
\end{abstract}

Key words: nonlinear dynamics, osillations, free oscillations, forced oscillations, discrete system, continuous system, oscillator.

\section{Introduction}

$\mathrm{N}$ EW analytical and numerical results of linear and nonlinear dynamics of two degrees of freedom system analysis are presented in our Reference [14]. For mechanical chain system with two degrees of freedom the oscillations in no resonant as well as resonant case expressions of solution are derived. In cited Reference [14], using a direct numerical experiment over the corresponding system of differential equations, a series of graphical presentations is presented. Comparison between linear and nonlinear system and oscillatory, free and forced dynamics gives some conclusions. Also, the analysis of the total mechanical energy of the system is analyzed. Using the Mihailo Petrovic's theory [20-22] of mathematical phenomenology elements and phenomenological mappings in vibrations, signals, resonances and dynamical absorptions in models of two degrees of freedom system dynamics - abstractions of different real system dynamics are identified and presented by a figure containing different physical models of dynamical systems. By using the mathematical description of a chain mechanical system with two mass particles coupled by linear elastic and nonlinear elastic springs and two degrees of freedom expressed by corresponding generalized independent coordinates translator displacements and corresponding analysis of solutions for free and forced vibrations series of corresponding two-frequency regimes and resonant states as well as dynamical absorption states are identified. Using these results and mathematical analogy and phenomenological mappings, it is possible to make a corresponding analysis of series of dynamics of other two degrees of freedom models and their dynamics (torsional system, double pendulum system, double electrical circuits).

In References [26-27], authored by Rašković D., the series of examples of electromechanical analogous vibration chain systems are presented. Mathematically described homogeneous chain dynamics and corresponding system of linear ordinary differential equations are solved by a trigonometric method for different cases of both end conditions.

The interest in the study of coupled plates as new qualitative systems [12-13] has grown exponentially over the last decades because of the theoretical challenges involved in the investigation of such systems. Recent technological

\footnotetext{
1) Mathematical Institute SANU, Knez Mihailova 36/III, 11000 Belgrade, SERBIA,

2) University of Belgrade, Institute of Chemistry, Technology and Metallurgy, Njegoševa 12, 11000 Belgrade, SERBIA

3) University of Niš, Faculty of Mechanical Engineering, Bulevar Nikole Tesle 55/16, 18000 Niš, SERBIA

4) University of Belgrade, Faculty of Physical Chemistry and Institute of Chemistry, Technology and Metallurgy, Studentski trg 12-16, 11000 Belgrade, SERBIA Correspondence to: Katica Stevanović Hedrih; e-mail: khedrih@sbb.rs
} 
innovations have caused a considerable interest in the study of component and hybrid dynamical processes of coupled rigid and deformable bodies (plates, beams and belts) denoted as hybrid systems, characterized by the interaction between subsystem dynamics, governed by coupled partial differential equations with boundary and initial conditions.

In References [23] "Phenomenological mapping" and [24] "Elements of mathematical phenomenology", as well as in "Mecanismes communs aux phenomenes disparates"[25], written by M. Petrović, the theoretical background for integrations of the results obtained in different areas of sciences on the basis of mathematical analogy is given.

References [18-21], by Mitropolyski, contain series of different asymptotic methods of nonlinear mechanics known as the Krilov-Bogolyubv-Mitropolyski asymptotic method that is applicable for investigation of the nonlinear phenomena around the known solutions of corresponding linear or nonlinear differential equations.

In the following, we shall analyze linear and nonlinear vibrations of a non-linear system with two deformable body degrees of freedom oscillations together with the comparison of vibration properties and related phenomena [14], [6], [1213], [23] and [8-9].

\section{Amplitude frequency graphs and interactions of nonlinear modes for small nonlinearity}

Let us consider two non-linear oscillators in an interaction by a non-linear spring. Corresponding system parameters are: $m_{1}, c_{1}, \tilde{c}_{1}, b_{1}$ and $m_{1}, c_{2}, \tilde{c}_{2}, b_{2}$ and for coupling spring $c, \tilde{c}$. These oscillators coupled by a spring present a chain nonlinear system with two-degrees of freedom. In Fig. 1 two nonlinear oscillators $\left(\mathrm{a}^{*}\right)$, each with one degree of freedom, excited each by one one-frequency external excitation $F_{0 i} \cos \left(\Omega_{i} t+\vartheta_{0 i}\right), i=1,2$ and $\left(b^{*}\right)$, two non-linear oscillators in interactions coupled by a nonlinear spring, are presented. In Fig.1(b*) coupled two oscillators present a new chain nonlinear system with twodegrees of freedom and loaded by two external forces with different forced frequencies. In Fig.1( $\left.\mathrm{c}^{*}\right)$ two nonlinear oscillators in interactions coupled by a nonlinear spring, a linear dempher and a rolling element [4.5] present a new chain nonlinear system with two-degrees of freedom and loaded by two external forces with different forced frequencies.

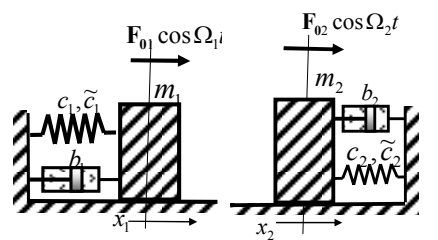

$\mathrm{a}^{*}$

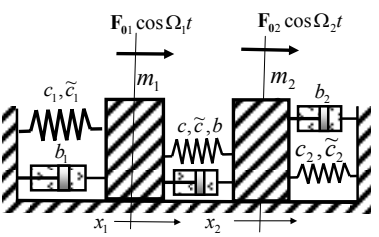

$\mathrm{b}^{*}$

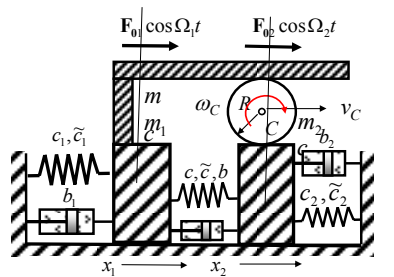

$\mathrm{c}^{*}$

Fugure 1. Two nonlinear oscillators ( $\left.a^{*}\right)$, each with one degree of freedom excited each by one frequency external excitation. $\left(b^{*}\right)$ Two oscillators in interactions coupled by a nonlinear spring - new chain nonlinear system with two-degrees of freedom and loaded by two external forces with different forced frequencies. ( $\left.\mathrm{c}^{*}\right)$ Two nonlinear oscillators in interactions coupled by a nonlinear spring, a linear damper and a rolling element - new chain nonlinear system with two-degrees of freedom and loaded by two external forces with different forced frequencies.
Energy change in each of the nonlinear oscillators with one degree of freedom is [4-6], [15]:

$$
\begin{gathered}
\frac{d}{d t}\left(E_{k(i)}+E_{p(i)}\right)=-2 \Phi_{(i)}+\dot{x}_{i} F_{0 i} \cos \left(\Omega_{i} t+\vartheta_{0 i}\right) \\
i=1,2
\end{gathered}
$$

Energy change in the system with coupled oscillators in the forced regime is:

$$
\frac{d}{d t}\left(E_{k}+E_{p}\right)=-2 \Phi+\sum_{i=1}^{i=2} \dot{x}_{i} F_{0 i} \cos \left(\Omega_{i} t+\vartheta_{0 i}\right)
$$

where the total mechanical energy is done by the known expression and the Railygh function of dissipation energy is in the form:

$$
\Phi=\Phi_{(1)}+\Phi_{(2)}+\Phi_{\text {inter }}=\frac{1}{2} \sum_{i=1}^{i=2} b_{i} \dot{x}_{i}^{2}+\frac{1}{2} b\left(\dot{x}_{2}-\dot{x}_{1}\right)^{2}
$$

System of governing differential equations for describing nonlinear dynamics of the coupled oscillators presented in Fig.1.b* are:

$$
\begin{aligned}
& \ddot{x}_{1}+2 \delta_{1} \dot{x}_{1}+\left(\omega_{1}^{2}+a_{1}^{2}\right) x_{1}-a_{1}^{2} x_{2}-2 \delta_{11}\left(\dot{x}_{2}-\dot{x}_{1}\right)= \\
& =-\tilde{\omega}_{N 1}^{2} x_{1}^{3}+\tilde{\omega}_{N 11}^{2}\left(x_{2}-x_{1}\right)^{3}+h_{01} \cos \left(\Omega_{1} t+\vartheta_{01}\right) \\
& \ddot{x}_{2}+2 \delta_{2} \dot{x}_{2}+\left(\omega_{2}^{2}+a_{2}^{2}\right) x_{2}-a_{2}^{2} x_{1}+2 \delta_{22}\left(\dot{x}_{2}-\dot{x}_{1}\right)= \\
& =-\tilde{\omega}_{N 2}^{2} x_{2}^{3}-\tilde{\omega}_{N 22}^{2}\left(x_{2}-x_{1}\right)^{3}+h_{02} \cos \left(\Omega_{2} t+\vartheta_{02}\right)
\end{aligned}
$$

where for $i=1,2, \omega_{i}^{2}=\frac{c_{i}}{m_{i}}, \tilde{\omega}_{N i}^{2}=\frac{\tilde{c}_{i}}{m_{i}}, \tilde{\omega}_{N i i}^{2}=\frac{\tilde{c}}{m_{i}}, 2 \delta_{i}=\frac{b_{i}}{m_{i}}$, $2 \delta_{i i}=\frac{b}{m_{i i}} a_{i}^{2}=\frac{c}{m_{i}}, h_{01}=\frac{F_{01}}{m_{1}}$.

For obtaining asymptotic approximation of solutions of the previous system (4) of non-linear differential equations for a small nonlinearity we take into account the case that external excitations are with small amplitudes of the forces and that $\Omega_{i} \approx \hat{p}_{i} . \quad i=1,2$ frequencies are in interval of the resonant range of eigen circular frequencies $\hat{p}_{i}$. $i=1,2$ of corresponding linear system to system (4). We propose the first asymptotic approximatin of solutions in the forms:

$$
\begin{aligned}
x_{1}(t) & =K_{21}^{(1)} e^{\delta_{1} t} R_{1}(t) \cos \Phi_{1}(t)+ \\
& +K_{21}^{(2)} e^{\delta_{2} t} R_{2}(t) \cos \Phi_{2}(t) \\
x_{2}(t) & =K_{22}^{(1)} e^{\delta_{1} t} R_{1}(t) \cos \Phi_{1}(t)+ \\
& +K_{22}^{(2)} e^{\delta_{12} t} R_{2}(t) \cos \Phi_{2}(t)
\end{aligned}
$$

where full phases $\Phi_{i}(t)=\Omega_{i} t+\varphi_{i}(t), \quad i=1,2$, and amplitudes $a_{i}(t)=e^{\delta_{i} t} R_{i}(t), \quad i=1,2 \quad$ and difference $\varphi_{i}(t)=\Phi_{i}(t)-\Omega_{i} t, i=1,2$, of the phases in first asymptotic approximations are difined by a system of differential equations of the first approximations along $R_{i}(t), i=1,2$, and

$\varphi_{i}(t), i=1,2$, in the following form [14-17], [2-3], [23] and [12-13]:

$$
\dot{R}_{1}(t)=-\frac{K_{22}^{(2)} e^{\delta_{1} t}}{\left[\hat{p}_{1}+\Omega_{1}(\tau)\right]\left[K_{21}^{(1)} K_{22}^{(2)}-K_{22}^{(1)} K_{21}^{(2)}\right]} h_{01} \sin \varphi_{1}(t)
$$




$$
\begin{aligned}
& \dot{\varphi}_{1}(t)=\hat{p}_{1}-\Omega_{1}(\tau)+\frac{3 K_{22}^{(2)}}{16 \hat{p}_{1}\left[K_{21}^{(1)} K_{22}^{(2)}-K_{22}^{(1)} K_{21}^{(2)}\right]} \tilde{\omega}_{N 1}^{2} \\
& \left\{e^{-2 \hat{\delta}_{1} t}\left(K_{21}^{(1)}\right)^{3}\left[R_{1}(t)\right]^{2}+2 e^{-2 \delta_{2} t} K_{21}^{(1)}\left[K_{21}^{(2)}\right]^{2}\left[R_{2}(t)\right]^{2}\right\}- \\
& -\frac{K_{22}^{(2)} e^{\delta_{1} t}}{\left[\hat{p}_{1}+\Omega_{1}(\tau)\right] R_{1}(t)\left[K_{21}^{(1)} K_{22}^{(2)}-K_{22}^{(1)} K_{21}^{(2)}\right]^{2} \cos \varphi_{1}(t)} \\
& \dot{R}_{2}(t)=-\frac{K_{21}^{(1)} e^{\delta_{2} t}}{\left[\hat{p}_{2}+\Omega_{2}(\tau)\right]\left[K_{21}^{(2)} K_{22}^{(1)}-K_{22}^{(2)} K_{21}^{(1)}\right]^{2} \sin \varphi_{2}(t)(6)} \\
& \dot{\varphi}_{2}(t)=\hat{p}_{2}-\Omega_{2}(\tau)+\frac{3 K_{21}^{(1)}}{16 \hat{p}_{2}\left[K_{21}^{(2)} K_{22}^{(1)}-K_{22}^{(2)} K_{21}^{(1)}\right]} \tilde{\omega}_{N 1}^{2} \\
& \left\{2 e^{-22 \hat{\delta}_{1} t}\left(K_{21}^{(1)}\right)^{3}\left[R_{1}(t)\right]^{2}+e^{-2 \hat{\delta}_{2} t} K_{21}^{(1)}\left[K_{21}^{(2)}\right]^{2}\left[R_{2}(t)\right]^{2}\right\}- \\
& -\frac{K_{21}^{(1)} e^{\delta_{2} t}}{\left[\hat{p}_{2}+\Omega_{2}(\tau)\right] R_{2}(t)\left[K_{21}^{(2)} K_{22}^{(1)}-K_{22}^{(2)} K_{21}^{(1)}\right]} h_{02} \cos \varphi_{2}(t)
\end{aligned}
$$

In the previous systems $K_{2 k}^{(s)}=K_{2 k}^{(s)}\left(\hat{p}_{s}\right), k=1,2 ; s=1,2$ are cofactors of characteristic determinant of the corresponding linear system to nonlinear, for characteristic number of the corresponding linear system to nonlinear, $\hat{p}_{i}$, $i=1,2$ are damped eigen circular frequencies - imaginary part of roots of characteristic determinant (equation) of the corresponding linear system to nonlinear, and $\delta_{i} i=1,2$ are real part of the roots of characteristic determinant (equation) of the corresponding linear system to nonlinear.

Previous system of differential equations (6) is to be analyzed numerically. For obtaining the stationary resonant amplitude-frequency and phase-frequency curves in the first approximation, it is necessary to put in the first aproximations along $\dot{a}_{i}(t)=0, \quad i=1,2$ and $\dot{\varphi}_{i}(t)=0, \quad i=1,2$ then we obtain the following nonlinear algebraic equations in the following form:

$$
\begin{gathered}
\dot{a}_{1}(t)=f_{1}\left(a_{1}(t), \varphi_{1}(t), a_{2}(t), \varphi_{2}(t), \Omega_{1}, \Omega_{2}\right)=0 \\
\dot{\varphi}_{1}(t)=f_{2}\left(\left(a_{1}(t), \varphi_{1}(t), a_{2}(t), \varphi_{2}(t), \Omega_{1}, \Omega_{2}\right)\right)=0 \\
\dot{a}_{2}(t)=f_{3}\left(\left(a_{1}(t), \varphi_{1}(t), a_{2}(t), \varphi_{2}(t), \Omega_{1}, \Omega_{2}\right)\right)=0 \\
\dot{\varphi}_{2}(t)=f_{4}\left(\left(a_{1}(t), \varphi_{1}(t), a_{2}(t), \varphi_{2}(t), \Omega_{1}, \Omega_{2}\right)\right)=0
\end{gathered}
$$

After the numerical analysis of the previous system of coupled algebraic nonlinear equations along the stationary values of stationary amplitudes $a_{i}(t)=e^{\delta_{i} t} R_{i}(t), i=1,2$, and stationary difference $\varphi_{i}(t)=\Phi_{i}(t)-\Omega_{i} t, i=1,2$, of the phases in the first asymptotic approximation and in different resonant frequency intervals of external excitation frequencies $\Omega_{i} \in\left(\hat{p}_{i}-\Delta \hat{p}_{i}, \hat{p}_{i}+\Delta \hat{p}_{i}\right), \quad i=1,2$, taking into account fixed discrete values of these frequencies $\Omega_{i} \approx \hat{p}_{i}, i=1,2$. Supposing that one external excitation frequency $\Omega_{2}$ or $\Omega_{1}$ is fixed, and the other changes for discrete values in interval around corresponding eigen damped circular frequency $\hat{p}_{i}, i=1,2$, it is possible to obtain numerous amplitude frequency and phase frequency graphs: $a_{i}(t)=g_{i}\left(\Omega_{1}, \Omega_{2}\right)$ and $\varphi_{i}(t)=\tilde{g}_{i}\left(\Omega_{1}, \Omega_{2}\right), i=1,2$, in case that $\Omega_{2} \neq$ cons $\tan t$ and $\Omega_{1}=$ const or $\Omega_{2}=$ const and $\Omega_{1} \neq$ const.
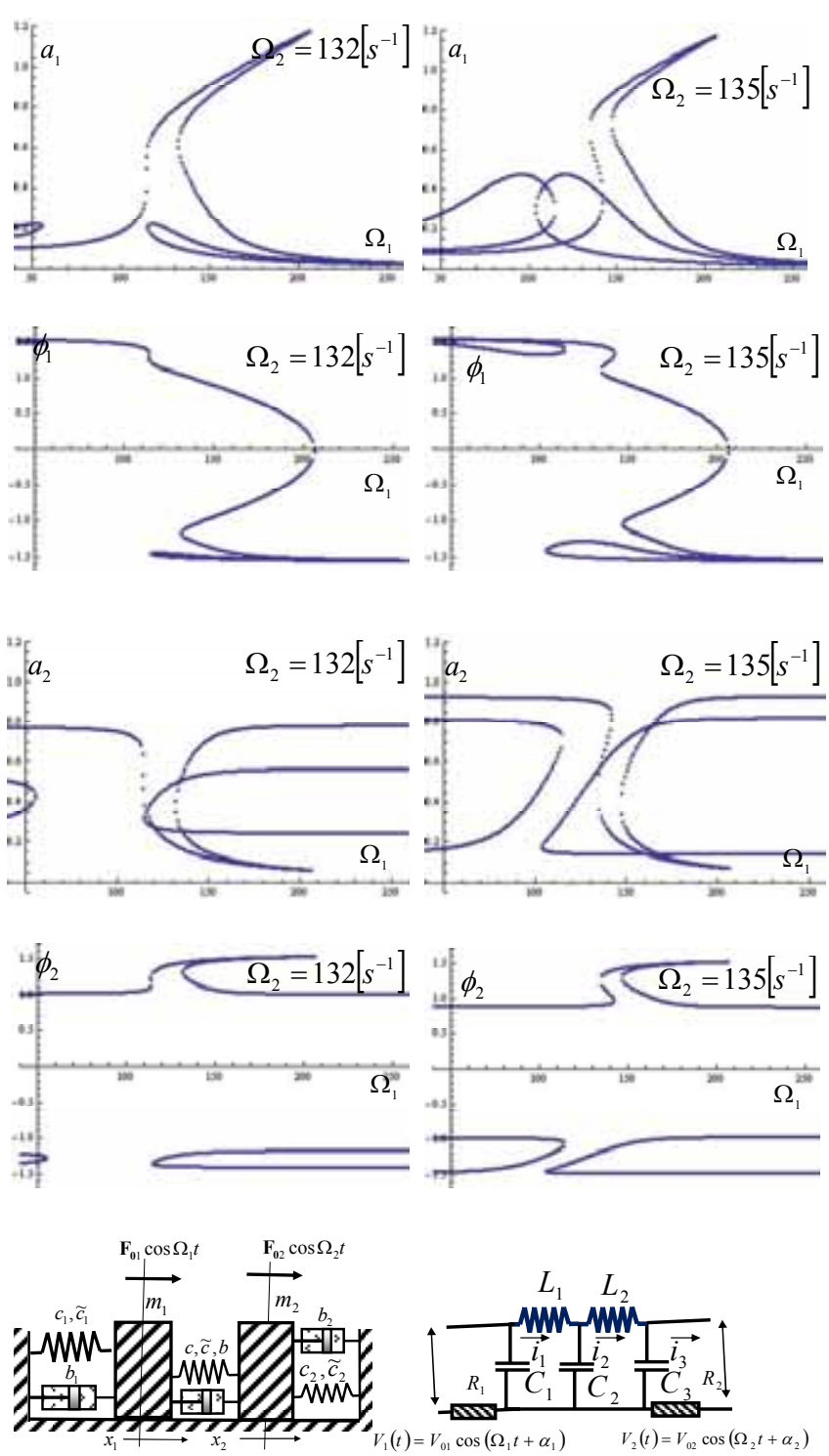

Figure 2. Amplitude-frequency and phase-frequency curve for a chain system with two-degrees of freedom in forced regime excited by external two forces with different frequencuies in stationary resonant regime: inteactions of forced nonlinear modes in analogous mechanical and electrical non-linear system.

Taking into account that the same type of the system of nonlinear differential equations in the first asysmptotic approximations (7) is obtained for the amplitudes and phases of eigen nonlinear modes amplitudes $a_{i}(t)=e^{\delta_{i} t} R_{i}(t), \quad i=1,2$ and stationary difference $\varphi_{i}(t)=\Phi_{i}(t)-\Omega_{i} t, \quad i=1,2$, of phases in the first asymptotic approximations of eigen time functions in one eigen amplitude mode of double plate system dynamics (for details see References [12, 13, 23] and similar [11]), it is possible to indicate a mathematical analogy and phenomenological approximate mappings between the amplitude frequency and phase frequency graphs: $a_{i}(t)=g_{i}\left(\Omega_{1}, \Omega_{2}\right)$ and $\varphi_{i}(t)=\tilde{g}_{i}\left(\Omega_{1}, \Omega_{2}\right), i=1,2$, in case that $\Omega_{2} \neq$ cons $\tan t$ and $\Omega_{1}=$ const or $\Omega_{2}=$ const and $\Omega_{1} \neq$ const . By using similar or same numerical data we can compose graphs of characteristic amplitude-frequency and phase-frequency curves presented in Figures 2 and 3 for qualitative properties of nonlinear phenomena in amplitudes and phases of mass particle displacements for most like two frequency regimes $[12,13,26]$. 
Table 1. Elements of qualitative and mathematical analogies of non-linear system dynamics energies: $a^{*}$ mechanical non-linear system and $b^{*}$ electrical non-linear system with two-degrees of freedom and $\mathrm{c}^{*}$ approximative energy carried on the eigen time function in one eigen amplitude form of double membrane oscillations coupled by non-linear discrete continuum dissipative layers

\begin{tabular}{|c|c|c|c|c|}
\hline & Kinetic energy & Potential energy & $\begin{array}{l}\text { Rayleigh function of energy } \\
\text { dissipation }\end{array}$ & Energy relations in fractional order sysem \\
\hline$a^{*}$ & $\begin{array}{l}\text { For mass particles } \\
2 \mathbf{E}_{k}=(\dot{x}) \mathbf{A}\{\dot{x}\} \\
(x)=\left(\begin{array}{ll}x_{1} & x_{2}\end{array}\right) \\
2 \mathbf{E}_{k}=\sum_{x=1}^{s=2} \dot{\eta}_{s}^{2} \\
\eta_{k} . \quad s=1,2 \text { eigen normal } \\
\text { coordinates (modes) of } \\
\text { displacements }\end{array}$ & 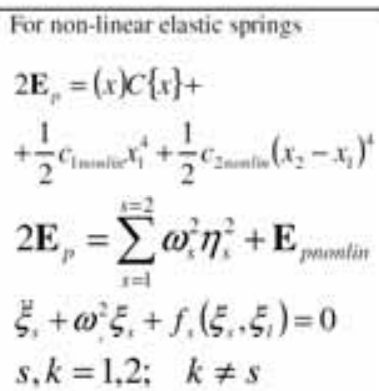 & $\begin{array}{l}\text { Power of linear dissipative forces in } \\
\text { sandard damping elements } \\
2 \Phi=(\dot{x}) \mathbf{B}\{\dot{x}\}\end{array}$ & $\begin{array}{l}\text { System total mechanical enengy rate } \\
\frac{d \mathbf{E}}{d t}=-2 \Phi \text {. Eigen main } \\
\text { for } \alpha \neq 0,0<\alpha<1\end{array}$ \\
\hline$b^{*}$ & 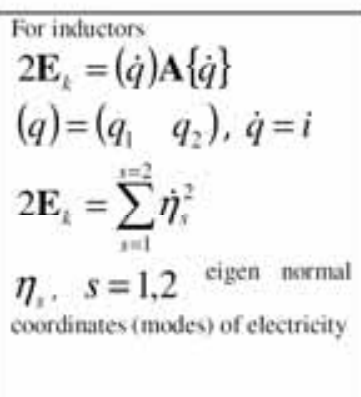 & 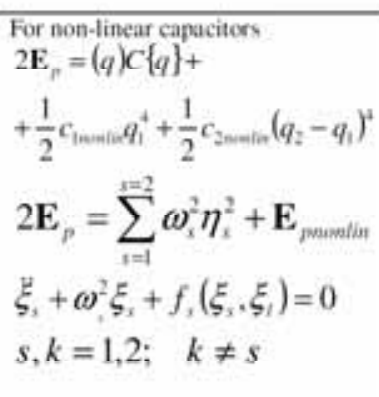 & $\begin{array}{l}\text { Power of dissipative electrical voltage } \\
\text { in standard lincar revistors } \\
2 \Phi=(\dot{q}) \mathrm{B}\{\dot{q}\}\end{array}$ & $\begin{array}{l}\text { Sysem total electrical energy rate } \\
\frac{d \mathbf{E}}{d t}=-2 \Phi\end{array}$ \\
\hline$c^{*}$ & 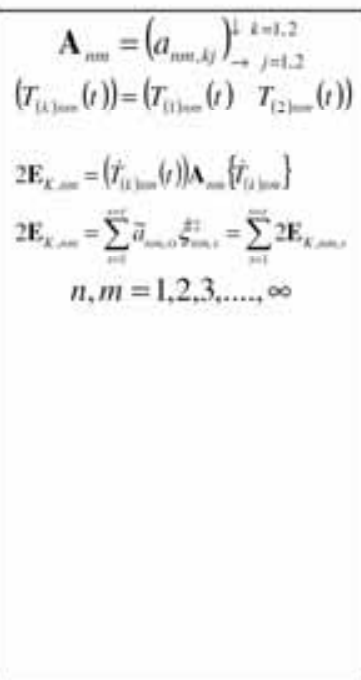 & 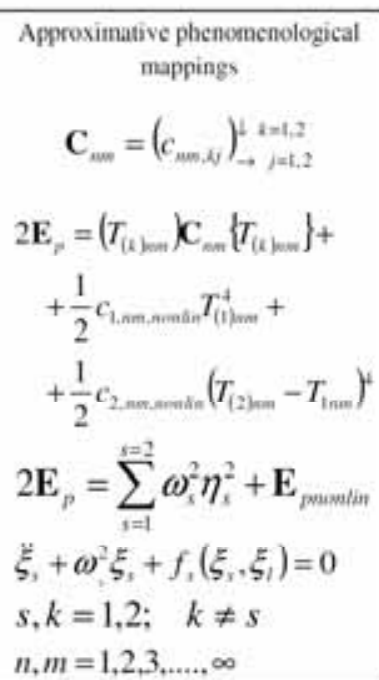 & $\begin{array}{l}\text { Approximative value of power of } \\
\text { linear dissipative forces in standard } \\
\text { damping elements cosreypond to one } \\
\text { cigen amplitude mode }\end{array}$ & $\frac{d \mathbf{E}_{-}}{d t}=-2 \Phi_{-}\left(T_{-}(t)\right)(t)$ \\
\hline
\end{tabular}
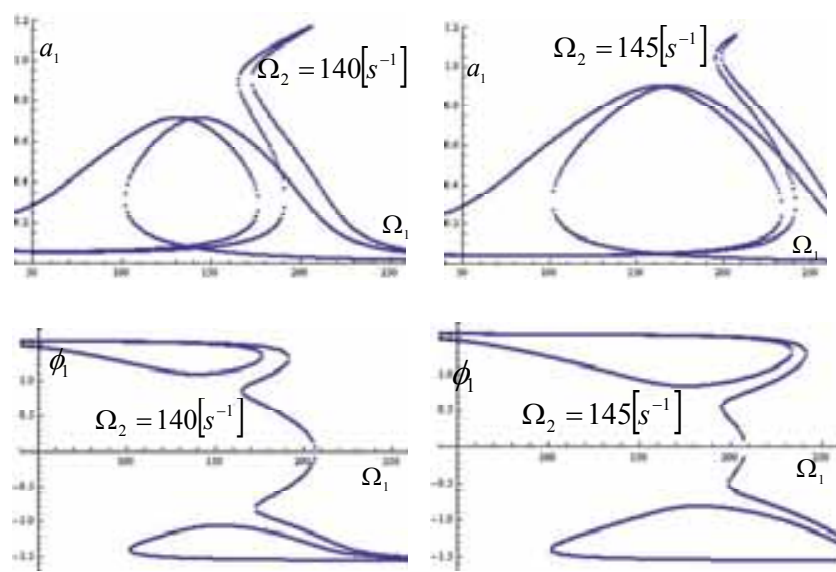

Figure 3. Amplitude-frequency and phase-frequency curve for a chain system with two-degrees of freedom in forced regime excited by the external two forces with different frequencies in the stationary resonant regime: interactions of forced nonlinear modes in analogous mechanical and electrical nonlinear system.
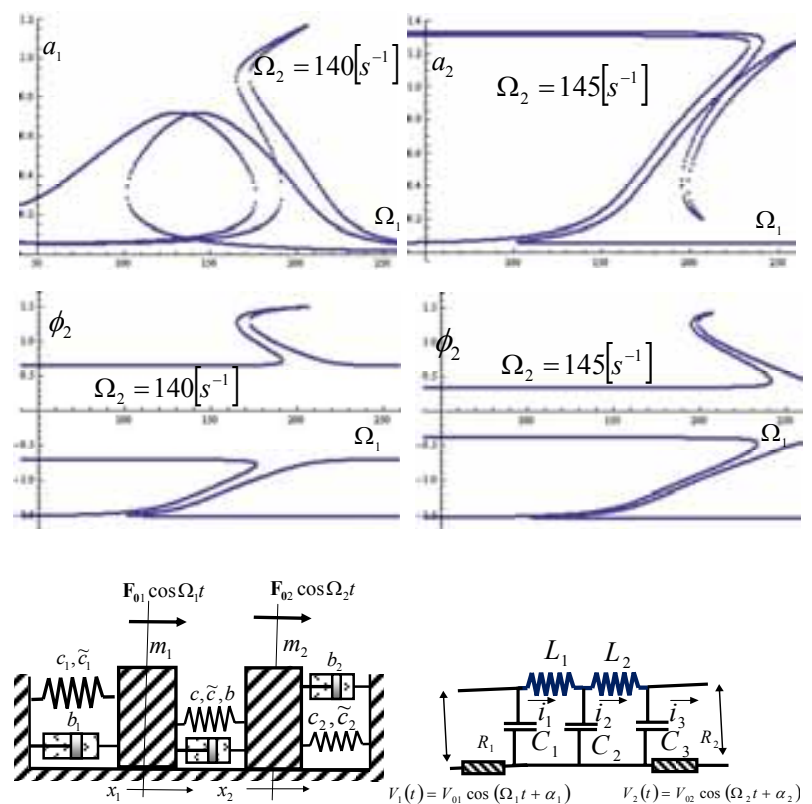
Table 2. Elements of mathematical phenomenology of a linear and a nonlinear dynamics system with one degree of freedom in forced regime under single frequency force and a system with two-degrees of freedom in forced regime excited by two periodic forces.

\begin{tabular}{|c|c|c|c|}
\hline & 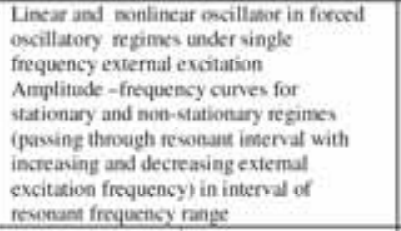 & 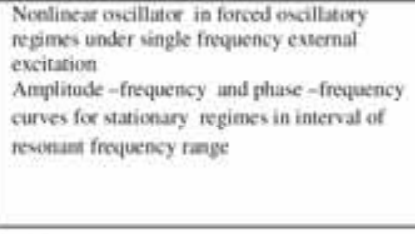 & 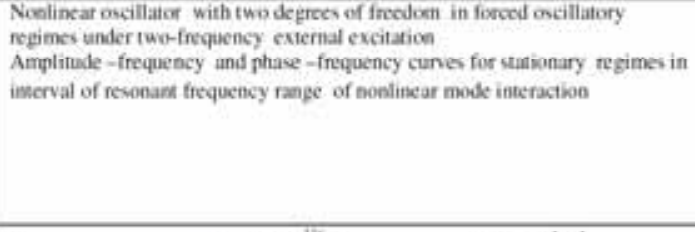 \\
\hline $\begin{array}{l}\text { Anplatude. } \\
\text { frequency and } \\
\text { phase-finguency } \\
\text { curves }\end{array}$ & a, whisintition & 4 & $=\frac{1}{a+1}$ \\
\hline $\begin{array}{l}\text { Diffenential } \\
\text { equadions }\end{array}$ & $\begin{array}{l}\ddot{\phi}+\omega_{0, i n}^{2} \varphi=\kappa_{3} \varphi^{3}+h_{0} \cos \Omega l \\
\ddot{\phi}+2 \delta \dot{\varphi}+\omega_{0, n_{i n}}^{2} \varphi=\kappa_{3} \varphi^{3}+h_{0} \cos \Omega\end{array}$ & $\ddot{\varphi}+2 \delta \dot{\varphi}+\omega_{a \sin }^{2} \varphi=\kappa_{3} \varphi^{3}+h_{0} \cos \Omega t$ & 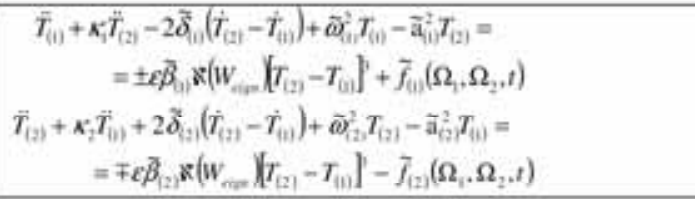 \\
\hline $\begin{array}{l}\text { Models of } \\
\text { mechanical } \\
\text { noelinear } \\
\text { oncillaton }\end{array}$ & $\underset{x}{c_{i}, c_{\text {monl }}, b} m$ & ${ }^{b} m_{\mathbf{F}}$ & 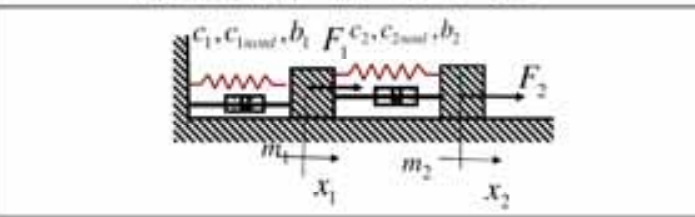 \\
\hline $\begin{array}{l}\text { Models of } \\
\text { electrical } \\
\text { nonlinear } \\
\text { oscillaton }\end{array}$ & 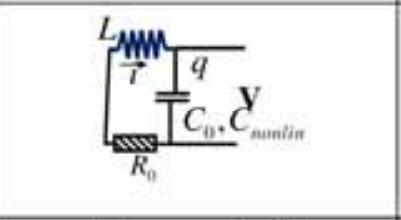 & 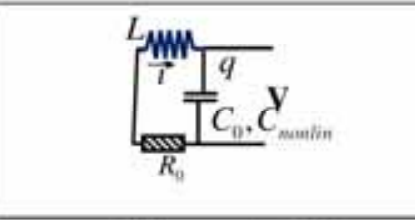 & 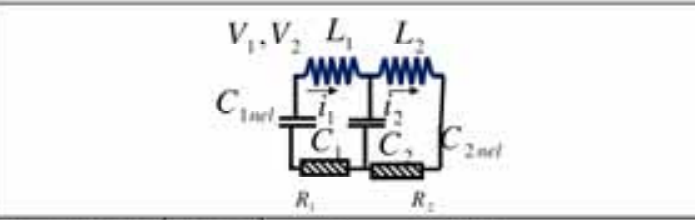 \\
\hline $\begin{array}{l}\text { System of first } \\
\text { asymptotic } \\
\text { approsimation } \\
\text { of amplitudes } \\
\text { and phases of } \\
\text { single or two- } \\
\text { frequency } \\
\text { asymptotic } \\
\text { apposimiation } \\
\text { of solution for } \\
\text { free vilurations }\end{array}$ & 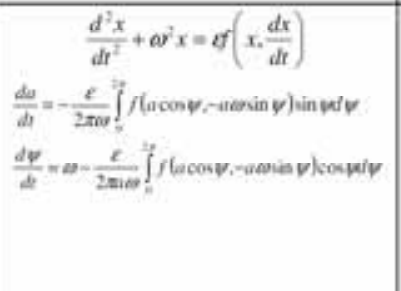 & 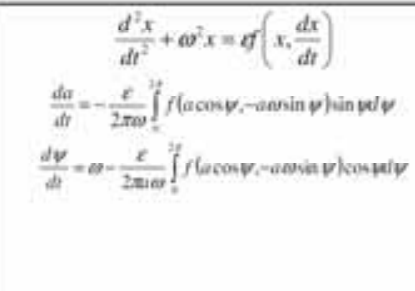 & 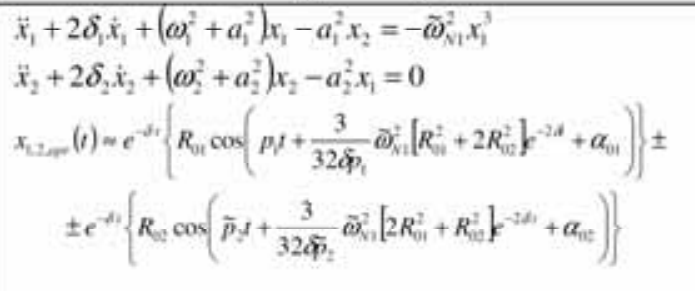 \\
\hline $\begin{array}{l}\text { System of fint } \\
\text { asymptotic } \\
\text { approvination } \\
\text { of amglitudes } \\
\text { and phiases of } \\
\text { single and two- } \\
\text { frequency } \\
\text { asymptotic } \\
\text { approsimation } \\
\text { of volution for } \\
\text { forced viturations }\end{array}$ & 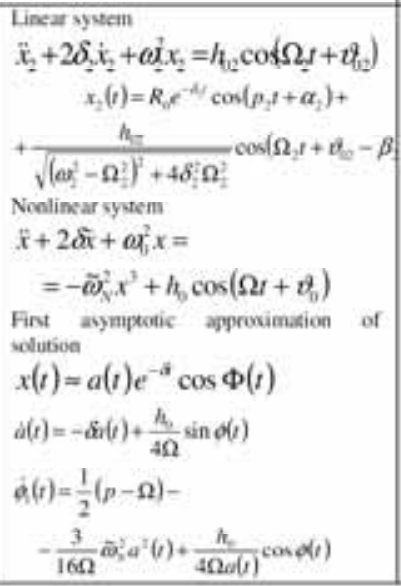 & 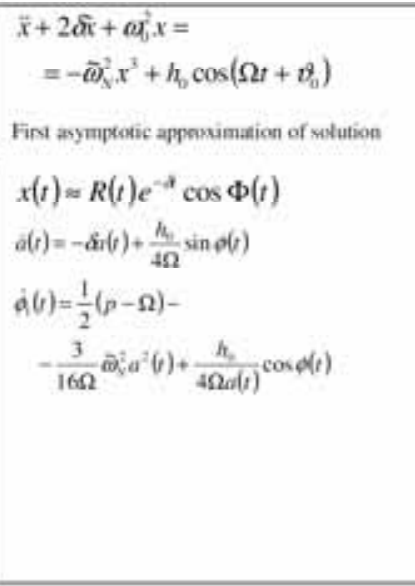 & 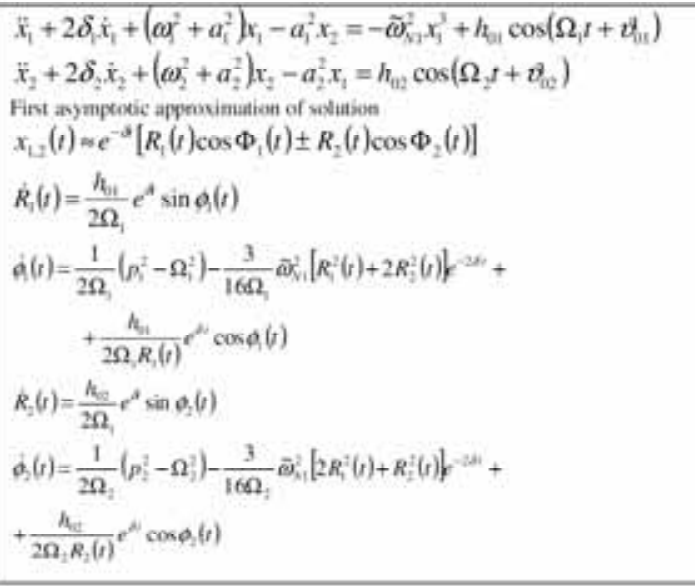 \\
\hline
\end{tabular}

It is visible that with the changes of discrete values of the first external excitation frequency in an interval $\Omega_{1} \in\left(\hat{p}_{1}-\Delta \hat{p}_{1}, \hat{p}_{1}+\Delta \hat{p}_{1}\right)$ and for a fixed value of the second external excitation frequency constant, $\Omega_{2}=$ const, it is possible to obtain different shapes of amplitude-frequency and phasefrequency curves $a_{i}(t)=g_{i}=\left(\Omega_{1}, \Omega_{2}\right)$ and $\varphi_{i}(t)=\tilde{g}_{i}\left(\Omega_{1}, \Omega_{2}\right)$ with stable and unstable values and branches [23].

In Figures 2 and 3, the electric chain system with two couples non-linear electrical circle containing a nonlinear capacitors, and excited by two periodical electric voltages $V_{0 i} \cos \left(\Omega_{i} t+\vartheta_{0 i}\right), \quad i=1,2$ are structural analogous with considered mechanical system and it is possible to indicate phenomenological mappings in asymptotic approximations of 
the nonlinear phenomena in stationary resonant regimes and to use amplitude-frequency and phase-frequency graphs for describing stationary resonant amplitudes and phases of capacitor charge during nonlinear vibrations. It is also possible to indicate resonant jumps in the capacitor charge.

In Table 1 the element of mathematical phenomenlogy of qualitative and mathematical analogies of a non-linear system of dynamics energies is presented: $a^{*}$ mechanical non-linear system with two-degrees of freedom and $b^{*}$ electrical nonlinear system with two-degrees of freedom and $\mathrm{c}^{*}$ approximative energy car ried on an eigen time function in one eigen amplitude form of a double membrane oscillation coupled by nonlinear discrete continuum dissipative layers.

In Table 2, in the first two columns, the elements of mathematical phenomenology of a linear and nonlinear dynamics system with one degree of freedom in the forced regime under single frequency force in mathematical analogy are presented. In Table 2, in the third column, the elements of mathematical phenomenology of a nonlinear system dynamics with two-degrees of freedom in the forced regime excited by two periodic forces with different frequencies are presented

\section{Structural analogy}

The Reference [18] is addressed to the phenomenological mapping and mathematical analogies of the oscillatory regimes in the systems of coupled deformable bodies. The systems consist of coupled deformable bodies like plates, beams, belts or membranes with corresponding boundary conditions (see Figures 4, 5 and 6) that are connected through visco-elastic non-linear layer, modeled by continuously distributed elements of the Kelvin-Voigt type with nonlinearity of the third order. Using the mathematical analogies, the similarities of structural models in the systems of plates, beams, belts or membranes are obvious. The structural models consist of a set of two or corresponding numbers of coupled non-homogenous partial non-linear differential equations. The problems to solve are divided into space and time domains by a classical Bernoulli-Fourier method. In the time domains the systems of coupled ordinary non-linear differential equations along eigen time functions in each eigen amplitude form are completely analog for different systems of deformable bodies and are solved by using the Krilov-Bogolyubov-Mitropolskiy asymptotic method [22-24]. This paper presents the beauty of mathematical analytical calculus which could be the same even for physically different systems.

The mathematical numerical calculus is a powerful and useful tool for making the final conclusions between too many input and output values. The conclusions about nonlinear phenomena in multi body systems dynamics have been revealed from the particular example of double plate's system stationary and no stationary oscillatory regimes.

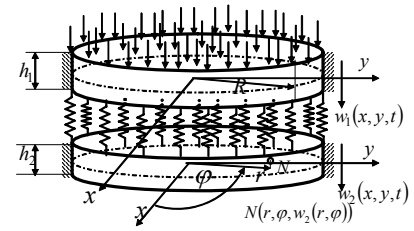

$a^{*}$

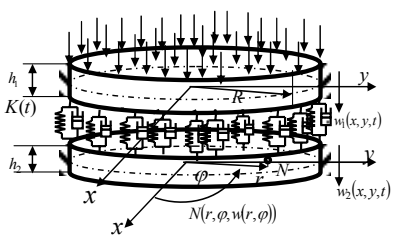

$b^{*}$
Figure 4. $a^{*}$ An elastically connected double circular plate system; b* A visco-elastically connected double circular plate system

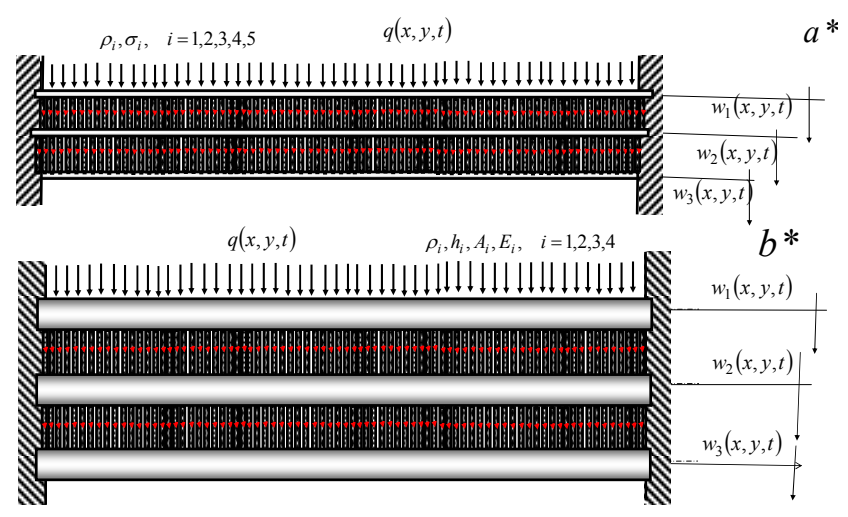

Figure 5. (a*) Three membranes (or plate) and (b*) three beams (or belts) coupled by standard discrete continuum fractional order layers into hybrid fractional order multi deformable body systems.

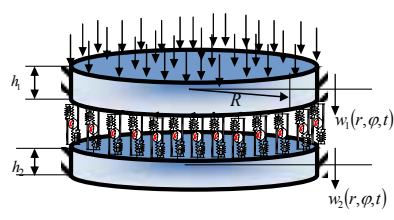

$\mathrm{a}^{*}$

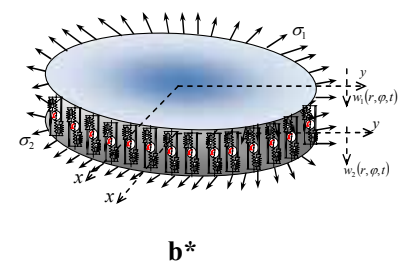

$B, A \ell$
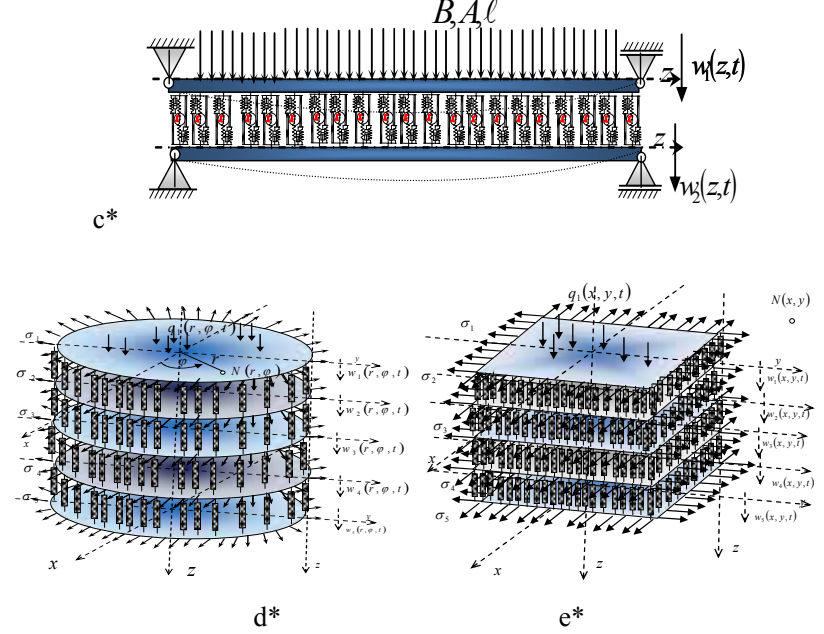

Figure 6. Models of hybrid multi deformable body systems with analogous eigen time functions in each of the corresponding eigen amplitude shape: $a^{*}$ two plate hybrid system coupled by visco-elastic fractional order layer with translator and rotator inertia properties, $\mathrm{b}$ * two membrane hybrid system coupled by visco-elastic fractional order layer with translator and rotator inertia properties and $\mathrm{c}^{*}$ two beam hybrid system with visco-elastic fractional order layer with translator and rotator inertia properties with analogous eigen time function in each of corresponding eigen amplitude shapes; $d^{*}$ five circular membrane hybrid system with viscoelastic fractional order layer and $\mathrm{e}^{*}$ five rectangular membrane hybrid system with visco-elastic fractional order layer with analogous eigen time function in each of corresponding eigen amplitude shapes.

Using the analytical results as well as numerical and graphical presentation of amplitude frequency graphs from paper [18] and analytical and numerical results presented in the previous part Amplitude frequency graphs and interactions of nonlinear modes for small nonlinearity, for nonlinear dynamics of chain system with two degrees of freedom, we can identify analogy between these listed results. Eigen time functions in each eigen amplitude form of coupled multi-bodies (plates, beams, belts or membranes) in a hybrid system are multi-frequency with accordance with a number of coupled bodies that correspond to the system dynamics of a chain with corresponding number of degrees of freedom. Analysis gives us structural, mathematical and qualitative analogies based on the elements of mathematical 
phenomenology [26-28] and [29-30]. Then all results of the analysis of linear and nonlinear dynamics with graphical presentation in our paper [14]: Oscillators: Phenomenological mappings and analogies - First part: Mathematical analogy and chains - , are useful to use for explanation nonlinear phenomena [15-17,8-9] of corresponding eigen time function in corresponding eigen amplitude form of transversal hybrid system that consists of multi bodies coupled by a discrete continuum layer, as in References [20], [4-6], [11-14] and [18-19]. The chapter is addressed to the phenomenological mapping and mathematical analogies of oscillatory regimes in systems of coupled deformable bodies (plates, beams, belts or membranes). On the basis of this theory it is possible to make the integration of contemporary knowledge obtained in various areas of sciences and to identify analogous dynamics and phenomena $[21,26,1,8-9,10]$. Phenomenological mapping of the phenomenon and models enables multiple system dynamics models of a disparate nature to be described by a single mathematical model. The well-known example is a mathematical analogy of electrical circuit consisting of a resistor, an inductor, and a capacitor, connected in series or in parallel with simple harmonic oscillator. Rašković [29-30] gives a series of examples for electromechanical mathematically analogous vibration systems mathematically described and solved for free vibrations.

The theory of Mihailo Petrović Alas, presented in two books and a paper [26-28], contains the elements of mathematical phenomenology and phenomenological mapping. Both publications were published in Serbian and only a small number of his contemporaries were able to read and understand this theory. The idea of mathematical phenomenology of M. Petrović was presented in his works entitled "Phenomenological Mapping" [25], containing the following chapters: The mapping of facts; General notation of mapping; Conventional mapping; Natural mapping; Mutual particularities of facts and Elements and properties (essentials) of facts. Alas's theory defines two tips of analogy: qualitative and mathematical analogy. "Phenomenological Mapping" by M. Petrović Alas and his mathematical phenomenology and mathematical analogy can be considered to be the continuation of the ideas of Poincare's mapping and as one of the researchers in the row leading to modern researchers who contributed to different kinds of mapping in the research of non-linear dynamics and dynamical systems. For example, nowadays, in the research of non-linear dynamics, Smale's horseshoe mapping is used in the vicinity of the homoclinic unstable point. At the time of the computer and software tool expansion, Roger Penrose (1989), and James Glaick (1987), had similar ideas that were later applied in graphical-computer techniques [18].

\section{Concluding Remarks}

In this paper, as well as in our previous one [14], new analytical and numerical results with corresponding graphical presentations of linear and nonlinear free and forced oscillations of two degrees of freedom chain system analysis are presented. Solutions for mechanical chain system with oscillations having two-degrees of freedom in no resonant as well as resonant case are derived. Also, a structural analogy is defined and an analogy between displacements of the chain oscillator with two degrees of freedom and eigen time functions of a double body hybrid system is pointed out.

The first asymptotic approximation of the solutions for mechanical nonlinear chain system with a small nonlinearity, having two-degrees of freedom in no resonant as well as stationary resonant cases is derived. By using direct analogy it is possible to apply these results to eigen time functions of double body hybrid system dynamics. Obtained amplitudefrequency and phase-frequency graphs for the chain system is possible to use for the analysis of the phenomena of eigen time functions of double body system dynamics defined in the paper.

Using the Mihailo Petrovic's theory of mathematical phenomenology elements, phenomenological mappings in linear and nonlinear vibrations, phenomena, signals, resonances and dynamical absorptions in models of two degrees of freedom system dynamics - abstractions of different real system dynamics are applicable for eigen time functions of transversal vibrations of double body system dynamics.

\section{Acknowledgment}

Parts of this research were supported by the Ministry of Education, Science and Technological Development of the Republic of Serbia trough the Mathematical Institute SANU Belgrade Grant OI 174001 " Dynamics of hybrid systems with complex structures. Mechanics of materials", the Faculty of Mechanical Engineering, University of Niš, and OI 172015 through the Faculty of Physical Chemistry, University of Belgrade and III 45001 Institute of Chemistry, Technology and Metallurgy, University of Belgrade, Department of Catalysis and Chemical Engineering, Belgrade.

\section{References}

[1] GOROŠKO,O.A., HEDRIH (STEVANOVIĆ),K.R.: Analitička dinamika (mehanika) diskretnih naslednih sistema, (Analytical Dynamics (Mechanics) of Discrete Hereditary Systems), University of Niš, 2001, Monograph, p. 426, YU ISBN 86-7181-054-2.

[2] HEDRIH (STEVANOVIĆ),K.R.: Modes of the Homogeneous Chain Dynamics, Signal Processing, Elsevier, 2006, 86, pp. 2678-2702.

[3] HEDRIH (STEVANOVIĆ),K.R.: Dynamics of coupled systems,. Nonlinear Analysis: Hybrid Systems, 2008, 2, pp. 310-334.

[4] HEDRIH (STEVANOVIĆ),K.R.: Energy interaction between linear and nonlinear oscillators (Energy transient through the subsystems in the hybrid system), Ukr. Mat. Zhurn., 2008, 60, pp. 796-814.

[5] HEDRIH (STEVANOVIĆ),K.R.: Energy analysis in the nonlinear hybrid system containing linear and nonlinear subsystem coupled by hereditary element, Nonlinear Dynamics, Springer, 30.01.2007, Vol.51, No.1, pp.127-140, DOI 10.1007/s11071-007-9197-2

[6] HEDRIH (STEVANOVIĆ),K.R.: Energy transfer in the hybrid system dynamics (energy transfer in the axially moving double belt system), Special Issue, Arch. of Applied Mech., 2009, Vol.79, No.6-7 pp. 529540, DOI 10.1007/s00419-008-0285-7.

[7] HEDRIH (STEVANOVIĆ),K.R., NIKOLIĆ-STANOJEVIĆ,V.: $A$ model of gear transmission fractional order system dynamics, Mathematical Problems in Engineering, 2010, Article ID 972873, 23 pages.

[8] HEDRIH (STEVANOVIĆ),K.R., KNEŽEVIĆ,R.: Structural stability of the planetary reductor nonlinear dynamics phase portrait, Facta Universitatis, 2000, Vol. 1, No. 7, pp. 911-923.

[9] HEDRIH (STEVANOVIĆ),K.R. KNEŽEVIĆ,R. CVETKOVIĆ,K Dynamics of planetary reductoe with turbulent damping, International Journal of Nonlinear Sciences and Numerical Simulations, 2001, Vol. 2, No. 3, pp. 265-262.

[10] HEDRIH (STEVANOVIĆ),K.R., HEDRIH,A.N.: Phenomenological mapping and dynamical absorptions in chain systems with multiple degrees of freedom, Journal of Vibration and Control 1077546314525984, first published on March 19, 2014 as doi: $10.1177 / 1077546314525984$

[11] HEDRIH (STEVANOVIĆ),K.R., KOZIĆ,P., PAVLOVIĆ,R.: $O$ uzajamnom Uticaju harmonika u nelinearnim sistemima sa malim parametrom, Zbornik radova Matematickog instituta, Nova Serija, knjiga 4 (13), 1984, pp.91-102,; Recueil des trawaux de L'Institute Mathematique, Nouvelle Serrie, tome 4 (13), 1984, pp. 91-102. 
[12] HEDRIH (STEVANOVIĆ),K.R., SIMONOVIĆ,J., (2012), Multifrequency analysis of the double circular plate system non-linear dynamics, NONLINEAR DYNAMICS, 2012 Springer, 2012, Vol.67, No.3, pp.2299-2315.

[13] HEDRIH (STEVANOVIĆ),K.R., SIMONOVIĆ,J.: (2010), Non-linear dynamics of the sandwich double circular plate system, Int. J. NonLinear Mech, November 2010, Vol.45, No.9, pp.902-918.

[14] HEDRIH(STEVANOVIĆ),K.R., IVANOVIĆ-ŠAŠIĆ,A., SIMONOVIĆ,J., KOLAR-ANIĆ,LJ., ČUPIĆ,Ž:: Oscillators: Phenomenological mappings and analogies - First part: Mathematical analogy and chains, Scientific Technical Review, ISSN 1820-0206, 2015, Vol.65, No.3, pp.27-38.

[15] HEDRIH (STEVANOVIĆ),K.R.: Основи теорије нелинеарних осиилација, Препринт, Машински факултет Ниш, 1975, стр. 500, PDF-e.library

[16] HEDRIH (STEVANOVIĆ),K.R.: Selected Chapters from Theory of Nonlinear Vibrations (in Serbian), Faculty of Mechanical Engineering, Niš, First Edition 1975), 1975, pp.180.

[17] HEDRIH (STEVANOVIĆ),K.R.: Study of Methods of Nonlinear Vibrations Theory (in Serbian), Poligraphy, Faculty of Mechanical Engineering, Niš, Preprint, 1972, pp.500.

[18] HEDRIH (STEVANOVIĆ),K.R., SIMONOVIĆ,J.: Structural analogies on systems of deformable bodies coupled with non-linear layers, International Journal Non-Linear Mechanics (January 6, 2014), Vol. 73, July 2015, Pages 18-24 Our reference: NLM2402, DOI: 10.1016/j.ijnonlinmec.2014.11.004

[19] HEDRIH (STEVANOVIĆ),K.R.: Multi membrane fractional order system vibrations, Theoretical and Applied mechanics, Series: Special Issue - Dedicated to memory of Anton D. Bilimovič (1879-1970), Guest Editors: Katica R. (Stevanović) Hedrih and Dragoslav Šumarac, 2014, Vol. 41 (S1), pp. 43-61.

[20] DOI: 10.2298/TAM14S1043H, ISSN 1450-5584

http://www.mi.sanu.ac.rs/projects/TAM-SpecialIssue41-2014BILIMOVIC.pdf

[21] HEDRIH (STEVANOVIĆ),K.R.: Elements of mathematical phenomenology in dynamics of multi-body system with fractional order discrete continuum layers, Dedicated to the 100th Anniversary of the Russian Academician Yury Rabotnov, Dedicated to Centennial Jubilee of Russian Academician Yury N. Rabotnov, Special issue of International Journal of Mechanics, 2014, Vol.8, pp.345-352, ISSN: 1998-4448.(Paper submitted in January 2014), Journal indexed in SCOPUS (http://www.naun.org/cms.action?id=2828). (u stampi).
[22] http://www.naun.org/main/NAUN/mechanics/2014/b042003-61.pdf

[23] KOLAR-ANIĆ, LJ., ČUPIĆ,Ž., VUKOJEVIĆ,V., ANIĆ,S.: Dinamika nelinearnih procesa (Dynamics of nonlinear processes), Fakultet za fizičku hemiju, Beograd, 2011, pp.403

[24] MITROPOLYSKIY,Yu.A.: Nonlinear Mechanics - Asymptotic Methods, Institut matematiki NAN Ukraini, Kiev, 1995, pp.397. (in Russian)

[25] MITROPOLYSKIY,Yu.A.: Problemi asimptoticheskoy teorii nestashionarnih kolebaniy (Problems of asymptotic theory of no stationary vibrations), Nauka Moskva, 1964. (in Russian).

[26] MITROPOLYSKIY,Yu.A., VAN DAO,N.: Lectures on Asymptotic Methods of Nonlinear Dynamics, Vietnam National University Publishing House, Hanoi, 2003, pp.494.

[27] NIKOLIĆ-STANOJEVIĆ,V,LJ., VELJOVIĆ,Ć. DOLIĆANIN,I.: $A$ New Model of the Fractional Order Dynamics of the Planetary Gears, Hindawi Publishing Corporation, Mathematical Problems in Engineering, Vol.2013, Article ID 932150, 14 pages, http://dx.doi.org/10.1155/2013/932150

[28] PETROVIĆ,M.: Fenomenološko preslikavanje (Phenomenological mapping), Srpska kraljevska akademija, Beograd, 1933, pp.33. (In Serbian)

[29] PETROVIĆ,M.: Elementi matematičke fenomenologije (Elements of mathematical phenomenology), Srpska kraljevska akademija, Beograd, 1911,pp.789.(In Serbian)

http://elibrary.matf.bg.ac.rs/handle/123456789/476?locale-attribute=sr

[30] PETROVIĆ,M.:Mecanismes communs aux phenomenes disparates, Paris 1921.

[31] RAŠKOVIĆ,D.: Teorija oscilacija (Theory of Oscillations), Naučna knjiga, 1952. (In Serbian)

[32] RAŠKOVIĆ,D.: Analitička mehanika, Mašinski fakultet Kragujevac, 1974.

[33] SIMONOVIĆ,J.: Non-Linear Dynamics of a Double-Plate System Coupled by a Layer with Viscoelastic and Inertia Properties, Scientific Technical Review, ISSN 1820-0206, 2012,Vol.62, No.1, pp.40-54.

\section{Oscilatori: Fenomenološko preslikavanje i analogije Drugi deo: Strukturna analogija i lanci}

Predstavljeni su novi analitički i numerički rezultati o dinamici linearnih i nelinearnih sistema sa sva stepena slobode kretanja. Za mehaničke sisteme sa dva stepena slobode kretanja izučavane su, analitički i numerički sa odgovarajućim poređenjima svojstava između sopstvenih i prinudnih režima, oscilatorne linearne i nelinearne dinamike u njima. Koristeći teoriju Mihaila Petroviċa - Elementi matematičke fenomenologije i Fenomenološko preslikavanje, u oscilacijama, signalima, fenomenima rezonancija i dinamičkoj apsorpciji u modelima sa dva stepena slobode dinamika apstrakcija različitih modela realnih sistema identifikovane su matematička $i$ kvailitativne analogije sa sopstvenim vremenskim funkcijama transverzalnih oscilacija sistema više spregnutih deformabilnih tela (ploča, greda, traka ili membrana) i predstavljene. Matematički opis jednog mehaničkog lanca sa dvema matrijalnim tačkama spregnutim linearno elastičnom ili nelinearno elastičnim oprugama i sa dva stepena slobode kretanja je prikazan zajedno sa odgovarajućom analizom kinetičkih parametara u analogiji sa sistemom dvaju spregnutih tela diskretno-kontinualnim spojem. Analizom odgovarajućih rešenja za sopstvene i prinudne dvofrekventne režime oscilacija i rezonantnih stanja, kao i stanja dinamičke apsorpcije došlo se do novih saznanja o interakciji modova u nelinearnoj dinamici. Korišćenjem matematičke analogije i fenomenološkog preslikavanja svojstvenih fenomena izučavanog mehaničkog sistema, pokazano je da se ta saznanja mogu koristiti za saznanja o fenomenima i svojstvima dinamika drugih apstrakcija realnih sistema modelima sistema sa dva stepena slobode oscilovanja (npr. dvojnog klatna, ili modela torzijskih oscilacija vratila sa dva diska, ili dvojnog električnog kola, kao i transverzalnih oscilacija spregnutih dveju greda, ili ploča ili membrana). Fenomenološko preslikavanje je koriščeno za objašnjavanje dinamike sopstvenih vremenskih funkcija u sistemu spregnutih jednakih deformabilnih tela (greda, ploča, ili membrana).

I u najkraćem, analitički i numerički rezultati linearnih i nelinearnih dinamika sistema sa dva stepena slobode su prikazani kao univerzalni, koji se mogu preneti i na razlićite druge sisteme analogijama i preslikavanjima linearnih i nelinearnih fenomena.

Ključne reči: nelinearna dinamika, oscilacije, sopstvene oscilacije, prinudne oscilacije, diskretni sistem, kontinualni sistem, oscilator. 


\title{
Осцилляторы: феноменологическое отображение и аналогии Вторая часть: структурная аналогия и цепочки
}

\begin{abstract}
Здесь представлены новые аналитические и численные результаты по динамике линейных и нелинейных систем со всеми степенями свободы движения. Для механических систем с двумя степенями свободы движения аналитически и численно изучаются колебательные линейные и нелинейные динамики в них, со соответствующими сравнениями свойств между собственными и вынужденными режимами. Используя теорию Михайла Петровича Элементы математической феноменологии и Феноменологические отображения, в колебаниях, в сигналах, в резонансных феноменах и в явлениях динамического поглощения в моделях с двумя степенями свободы движения динамики абстракции различных моделей реальных систем, были определены и представлены математические и высококачественные аналогии со собственными функциями времени поперечных колебаний системы более соединённых деформируемых тел (плиты, плитки, полосы или мембраны). Математическое описание одной механической цепи с двумя материальными точками в сочетании с линейными упругими или нелинейными упругими пружинами и с двумя степенями свободы движения показано вместе с соответствующим анализом кинетических параметров по аналогии с системой двух соединённых тел при помощи дискретно-непрерывного соединения. Анализом соответствующих решений для их собственных и вынужденных двухчастотных режимов колебаний и резонансных состояний, а также и состояний динамического поглощения, получены новые выводы и результаты о режимах взаимодействия в нелинейной динамике. С использованием математической аналогии и феноменологического отображения характерных явлений и феноменов иследованной механической системы, было показано, что эти знания и результаты могут быть использованы как выводы о феноменах и явлениях и свойствах динамик некоторых другых абстракций реальных систем при помощи модели систем с двумя степенями свободы колебаний (например, двойного маятника, или модели крутильных колебаний вала с двумя дисками, или двойной электрической схемы, а также и поперечных колебаний между двумя соединёнными балками, или пластинами, или мембранами). Феноменологическое отображение было использовано для объяснения динамики собственных функций времени в системе соединённых идентичных деформируемых тел (балки, плиты или мембраны). Короче говоря, аналитические и численные результаты линейных и нелинейных динамик систем с двумя степенями свободы движения представлены как универсальные, которые могут быть переданы в различные другие системы путём аналогий и отображений линейных и нелинейных явлений и феноменов.
\end{abstract}

Ключевые слова: нелинейная динамика, колебания, собственные колебания, вынужденные колебания, дискретная система, непрерывная система, осциллятор.

\section{Oscillateurs: correspondance phénoménologiques et analogies Deuxieme partie: analogie structurale et les chaînes}

Les nouveaux résultats analytiques et numériques pour la dynamique des systèmes linéaires et non linéaires concernant tous les degrés de liberté de mouvement sont présentés dans ce papier. Pour les systèmes mécaniques à deux degrés de liberté de mouvement on a étudié numériquement et analytiquement, avec les correspondances entre les régimes libres et forcés, les dynamiques oscillatoires linéaires et non linéaires. En usant la théorie de Mihailo Petrovic « Eléments de la phénoménologie mathématique « et «Correspondance phénoménologique « chez les oscillateurs, les signaux, les résonances et l'absorption dynamique dans les modèles à deux degrés de liberté - abstraction de différents systèmes réels dynamiques ont été identifiés comme les analogies mathématique et qualitative avec les fonctions temporelles des systèmes d'oscillations transversales des corps couplés multi déformables (plaques, rubans ou membranes) et présentés. La description d'une chaîne mécanique à deux points matériels couplés linéairement par les ressorts élastiques linéaires ou non linéaires et à deux degrés de liberté de mouvement est présenté avec l'analyse des paramètres cinétiques. En analysant les solutions pour les régimes des oscillations propres ou forcées à deux fréquences ainsi que les états de résonance et de l'absorption dynamique on a identifié les nouvelles connaissances sur l'interaction des modes dans la dynamique non linéaire. Par l'analogie mathématique et la correspondance phénoménologique des phénomènes du système mécanique étudié on a démontré que ces connaissances pouvaient s'utiliser pour examiner les propriétés de la dynamique chez les autres abstractions des systèmes réels (par exemple : double pendule, modèle d'oscillations torses d'ensouple à deux disques, circuit électrique double, oscillations transversales des deux poutres couplées, plaques et membranes). La correspondance phénoménologique s'utilise pour expliquer la dynamiques des fonctions temporelles propres dans le système des corps identiques couplés et déformables (poutres, plaques ou membranes). En bref les résultats analytiques et numériques des dynamiques linéaires ou non linéaires du système à deux degrés de liberté sont présentés comme universels et peuvent s'employer chez les autres systèmes par analogie et correspondances des phénomènes linéaires ou non linéaires.

Mots clés: dynamique non linéaire, oscillations, oscillations propres, oscillations forcées, système discret, système continu, oscillateur. 